\title{
A new lithophylacid crab (Crustacea, Decapoda, Portunoidea) from the Late Cretaceous (early Maastrichtian) of Cuba
}

\section{Un nuevo cangrejo litofilácido (Crustacea, Decapoda, Portunoidea) del Cretácico Tardío (Maastrichtiano temprano) de Cuba}

Francisco J. Vega ${ }^{1, *}$, Carlos Rafael Borges-Sellén², Javier Aguilar-Pérez ${ }^{3}$, Alberto F. Arano-Ruiz ${ }^{2}$, Lázaro W. Viñola-López ${ }^{4}$, Torrey Nyborg ${ }^{5}$

${ }^{1}$ Instituto de Geología, Universidad Nacional Autónoma de México, Ciudad Universitaria, Coyoacán, 04510, CDMX, Mexico.

${ }^{2}$ Sociedad Cubana de Geología, Cienfuegos, Cuba.

${ }^{3}$ Facultad de Ciencias de la Tierra, Universidad Autónoma de Nuevo León, Carretera a Cerro Prieto Km 8, Ex-Hacienda de Guadalupe, 67700, Linares, Nuevo León, Mexico.

${ }^{4}$ Florida Museum of Natural History, University of Florida, Gainesville, FL 32611-7800, Florida, United States of America.

${ }^{5}$ Department of Earth and Biological Sciences, Loma Linda University, CA92350, Loma Linda, California,United States of America.

* Corresponding author: (F. Vega) vegver@unam.mx

\section{How to cite this article:}

Vega, F.J., Borges-Sellén, C.R., Aguilar-Pérez, J., Arano-Ruiz, A.F., Viñola-López, L. W., Nyborg, T., 2021, A new lithophylacid crab (Crustacea, Decapoda, Portunoidea) from the Late Cretaceous (early Maastrichtian) of Cuba: Boletín de la Sociedad Geológica Mexicana, 73 (1), A220620. http://dx.doi.org/10.18268/ BSGM2021v73n1a220620

\footnotetext{
Manuscript received: June 6, 2020

Corrected manuscript received: June 20, 2020

Manuscript accepted: June 25, 2020

Peer Reviewing under the responsibility of Universidad Nacional Autónoma de México.

\begin{abstract}
Icriobranchiocarcinus rodas Vega n. sp., is recorded from lower Maastrichtian (Upper Cretaceous) Arroyo Grande Formation near the town of Rodas (Central Cuba). I. rodas Vega n. sp. represents additional evidence of paleobiogeographic affinities between Chiapas (SE Mexico) and Cuba, during the Late Cretaceous. The genus Icriobranchiocarcinus Vega, 2018 in Vega et al., 2018 was erected from the type species Icriobranchiocarcinus tzutzu Vega, 2018 from the lower Maastrichtian Ocozocoautla Formation (Chiapas). I. rodas Vega, n. sp. preserves details of ventral morphology as well as more details of chelipeds not reported in $I$. $t z u t z u$, adding to the morphology of the genus. Icriobranchiocarcinus belong to a family (Lythophylacidae Van Straelen, 1936) that became extinct worldwide during the $\mathrm{K} / \mathrm{Pg}$ event.
\end{abstract}

\section{Keywords: Decapoda, Portunoi} dea, Icriocarcininae, early Maastrichtian, Cuba.

\section{RESUMEN}

Icriobranchiocarcinus rodas Vega n. sp., es reportada del Maastrichtiano inferior (Cretácico Superior) de la Formación Arroyo Grande, cerca del pueblo de Rodas (Cuba Central). Icriobranchiocarcinus rodas representa evidencia adicional acerca de las afinidades paleobiogeográficas entre Chiapas (SE México) y Cuba durante el Cretácico Tardio. El género Icriobranchiocarcinus Vega, 2018 en Vega et al., 2018, fue creado a partir de la especie tipo Icriobranchiocarcinus tzutzu Vega, 2018 del Maastrichtiano inferior de la Formación Ocozocoautla. I. rodas Vega n. sp., preserva detalles de la morfología ventral, así como mayor detalle de los quelípedos, no reportados previamente en I. tzutzu , añadiendo características de la morfología del género. Icriobranchiocarcinus pertenece a una familia (Lythophylacidae Van Straelen, 1936) extinta durante el evento $\mathrm{K} / \mathrm{Pg}$ event alrededor del mundo.

Palabras clave: Decapoda, Portunoidea, Icriocarcininae, Maastrichtiano temprano, Cuba. 


\section{Introduction}

Decapod Cretaceous crabs from Cuba are rather scarce in the literature (Pszczółkowski, 2002, Varela and Rojas-Consuegra 2011, Arano-Ruiz et al. 2018).

Pszczółkowski (2002) and Vega et al., (2020) reported the presence of burrows referred to the ichnogenus Thalassinoides (Ehrenberg, 1944) from marls assigned to the Vaquería Formation in Central Cuba, with infill of these burrows in limestones being dated as late Maastrichtian from microfossil evidence. Varela and Rojas-Consuegra (2009) described a nearly complete raninid carapace from the Upper Cretaceous of Central Cuba as Vegaranina precocia Feldmann, Vega, Tucker, Garcia-Barrera, Avendaño, 1996, a species first reported from the upper Maastrichtian "Ocozocoautla Formation" in central Chiapas, Mexico (Feldmann et al., 1996).
Later, Arano-Ruiz et al. (2018) redescribed the Cuban specimen, as well as two other partial carapaces as a new species, Vegaranina rivasi Arano-Ruiz, Viñola-López, Rojas-Consuegra and Borges-Sellen, 2018, from the upper Campanian-lower Maastrichtian Monos Formation, rather than from the Cotorro Formation, as Varela and Rojas-Consuegra (2009) indicated in the original description of $V$ precocia. More recently and associated with the new species herein described, Vega et al. (2020) described Graptocarcinus collinsi Vega, 2020, based on well-preserved carapaces from the lower Maastrichtian Arroyo Grande Formation, near its basal contact with the upper portion of the late Campanian Monos Formation (Figure 1). The purpose of this work is to report a new species of a widely distributed portunoid subfamily during the Late Cretaceous in the Caribbean Region and SE of North America.

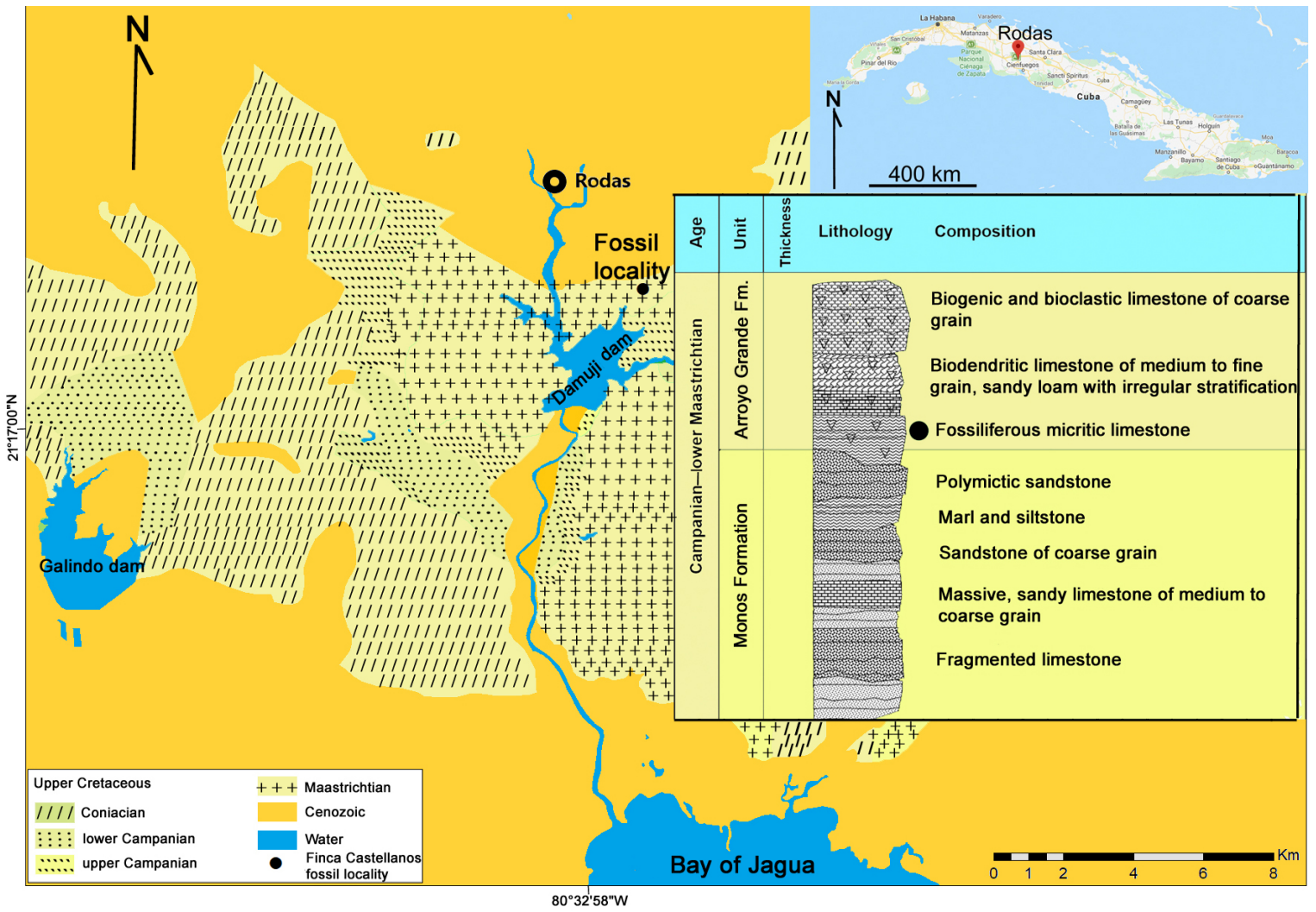

Figure 1 General location of study area showing detailed map of outcrop with geologic map and simplified stratigraphic section of fossil locality. Detailed map of outcrop on the geological map, SE Rodas. Simplified stratigraphical section of the locality; black dot indicates provenance of specimens described herein, collected near Finca Castellanos. Modified from Arano et al., (2018) and fitted to colors of the 2020 International Chronostratigraphic Chart, https://stratigraphy.org/icschart/ChronostratChart2020-01.pdf 


\section{Geological setting}

The fossils herein described were collected in the Arroyo Grande fossil locality (Figure 2). situated near Finca Castellanos, about $4 \mathrm{~km}$ southeast of the town of Rodas in Cienfuegos Province, Central Cuba (Figures 1 and 2). Specimens were collected in situ from calcareous detritus of the Arroyo Grande Formation, which is characterized by the alternation of limestone, sandstone, conglomerate, and marl (Linares-Cala, 2014). These sediments were deposited on a neritic platform that originated when the sea covered part of the Proto-Caribbean extinct volcanic arch in the Late Cretaceous (Iturralde-Vinent, 2006). Bioherms and other reef structures are locally found across limestone outcrops in the Arroyo Grande and other formations of similar age in the region (Linares-Cala, 2014).

\section{Anatomical abbreviations used in descriptions and figures}

$b a=$ basis, $b r=$ branchial ridge, $c a=$ carpus, $c r r=$ cardiac ridge, $c x=$ coxa, $d a=$ dactylus, $e 1 e=$ cervical

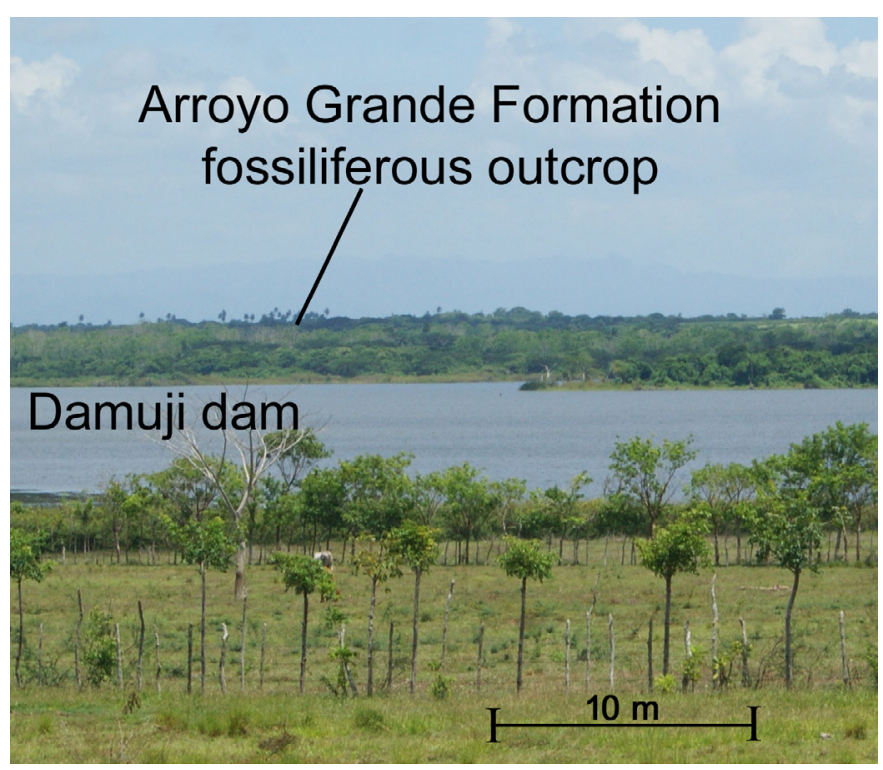

Figure 2 Landscape indicating position of fossiliferous locality near Damuji dam. groove, $e b r=$ epibranchial ridge, $e g / b r=$ epigastric/branchial ridge; $e n=$ endopod, $e p r=$ epigastric ridge, $e x=$ exopod, $f x f=$ fixed finger, her $=$ hepatic ridge, $i$ tr $=$ intestinal ridge, $i s q=$ ischium, $L c h=$ left cheliped, $L s=$ lateral spines 1-4, mer = merus, $m s b r=$ mesobranchial ridge, $m s g r=$ mesogastric ridge, $m t b r=$ metabranchial ridge, $m \times 3=$ third maxilliped, $o k=$ outer keel of propodus, orb $=$ orbit, $o s=$ orbital spine, $p=$ pereiopods $2-4$, pls $=$ abdominal somites $1-6, p r=$ propodus, $p \operatorname{tg} r=$ protogastric ridge, $p t p=$ protogastric process, $r c h=$ right cheliped, $r o=$ rostrum, $r t=$ row of tubercles 2 and 3, sos $=$ suborbital spine, $s t=$ sternites $1-7$, te $=$ telson, $u g r=$ urogastric ridge.

\section{Systematic paleontology}

Note: Specimens described and illustrated here are deposited in the Colección Nacional de Paleontología, Instituto de Geología, Universidad Nacional Autónoma de México, Mexico City CDMX, 045 10, Mexico (abbreviation: IGM).

Section Eubrachyura Saint Laurent de, 1980

Subsection Heterotremata Guinot, 1977

Superfamily Portunoidea Rafinesque, 1815

Family Lithophylacidae Van Straelen, 1936

Subfamily Icriocarcininae Števčić, 2005.

Genera included.- Icriocarcinus Bishop, 1988; Branchiocarcinus Feldmann and Vega, in Vega et al. (1995); Icriobranchiocarcinus Vega, 2018 in Vega et al. (2018), and possibly Cancrixantho Van Straelen, 1934.

Genus Icriobranchiocarcinus Vega, 2018 in Vega et al., 2018

Type species.- Icriobranchiocarcinus tzutzu Vega, 2018 (in Vega et al., 2018, p. 336, fig. 10.1-10.7, by monotypy).

Diagnosis.- Carapace small to medium, inverted subtrapezoidal, twice as wide as long, widest at level of sharp, front-directed orbital spines; anterior 
margin represents the widest portion of carapace, central portion of anterior margin straight, with relatively deep fissures at level of epigastric-branchial groove, anterior margin curves toward orbital spine, rostrum narrow, long, downturned, t-shaped at tip, eyestalks long and slender, distal portion reaches orbital spine; orbits wide, ovate; lateral margin straight, inclined, slightly arched with four lateral spines, posterior one being stronger; posterior margin slightly convex, rimmed, one-third the maximum carapace width; dorsal carapace regions marked by strong transverse ridges and relatively deep grooves; sharp transverse ridges on protogastric, mesogastric, urogastric, cardiac, intestinal, hepatic, epibranchial, branchial, mesobranchial, metabranchial regions; sternum wide, transversely subovate, widest at midlength, st3 transversely subtrapezoidal, st 4 subtrapezoidal, st 5 transversely subrectangular, st6 similar to st5, st7 rectangular, st8 small and subquadrate, episternal process of st4-6 inverted, triangular; pleon triangular, telson triangular, pleonal somite 6 subtrapezoidal, pleonal somite 5 subrectangular, pleonal somites 4 and 3 similar to pleonal somite 5 , pleonal somite 2 folded in the middle by transverse ridge, about as long but one-third narrower than pleonal somite 3, pleonal somite 1, only visible on dorsal position, semi-triangular, as wide as pleonal somite 2 but twice its length; endopodite of third maxilliped inverted subtrapezoidal; chelipeds slightly unequal, right chela slightly larger than left, coxa concave, basis subtrapezoidal inverted, ischium conical, merus robust, with three meral spines on ventral surface, carpus also robust, but one-third the length of merus, with strong spine on inner distal margin, propodus robust, subrectangular elongated, with four strong transverse outer keels that run from base of propodus to distal margin, dorsal surface of propodus with one anterior smooth ridge and two posterior rows of tubercles, ventral margin with fine tubercles; dorsal surface of dactylus with row of longitudinal spines; p2-p5 long, slender, p3 and p4 the longest and stronger, p5 well developed, nearly subdorsal, p2-p5 meri with median longitudinal sulcus, become stronger at distal portion, dactily unciform, with two lateral rows of fine tubercles.

Discussion.- In talking about the genus Cancrixantho, Phillips et al. (2013, p. 151) wrote: "The sole known specimen of the carcineretid Cancrixantho Van Straelen, 1934, from the Campanian of Spain, is similar to the Icriocarcinidae in its anterior margin, pseudorostrum, and dorsal carapace. It also has spines on the posterolateral margin, but the original shape of the carapace has been lost ... more complete specimens may reveal that Cancrixantho (currently in the Carcineretidae) may instead belong to the Icriocarcinidae, thus extending the paleobiogeographic and biostratigraphic range of the family". Possibly derived from the Lithophylacinae, the Icriocarcininae had a wide distribution and diversification during Late Cretaceous times.

Icriobranchiocarcinus rodas Vega, n. sp.

Figures $3 \mathrm{~A}$ to $3 \mathrm{I}, 4 \mathrm{~A}$ to $4 \mathrm{H}, 5 \mathrm{~A}, 5 \mathrm{C}$ and $5 \mathrm{E}$

Etymology.- The specific epithet refers to the Rodas town, East-central Cuba, Cienfuegos Province, West Cuba.

Material and locality.- Holotype IGM 11515 and paratype IGM 11516, Finca Castellanos, 4 $\mathrm{km}$ SE Rodas, at $22^{\circ} 18^{\prime \prime} 47^{\prime} \mathrm{N}$ and $80^{\circ} 31^{\prime \prime} 57^{\prime} \mathrm{W}$, lower Maastrichtian Arroyo Grande Formation, E-central Cuba.

Measurements (in mm).- Holotype IGM 11515 , length $=30.1$, width $=41.9$; paratype IGM 11516 , length $=37.2$, width $=38.6$.

Diagnosis.- Carapace of medium size, inverted subtrapezoidal, widest at anterior margin, sharp triangular orbital spines; anterior margin with finely serrated supraorbital margin, rostrum thin and short; lateral margin with four spines; posterior margin slightly convex; dorsal carapace regions marked by strong transverse ridges and grooves; orbits subovate, with prominent, sharp suborbital spine projected beyond anterior margin; dorsal carapace regions with strong transverse ridges and grooves; sternum subtriangular, sternites 1 to 7 visible on ventral view; abdomen wide, triangular; telson triangular, abdominal somites 

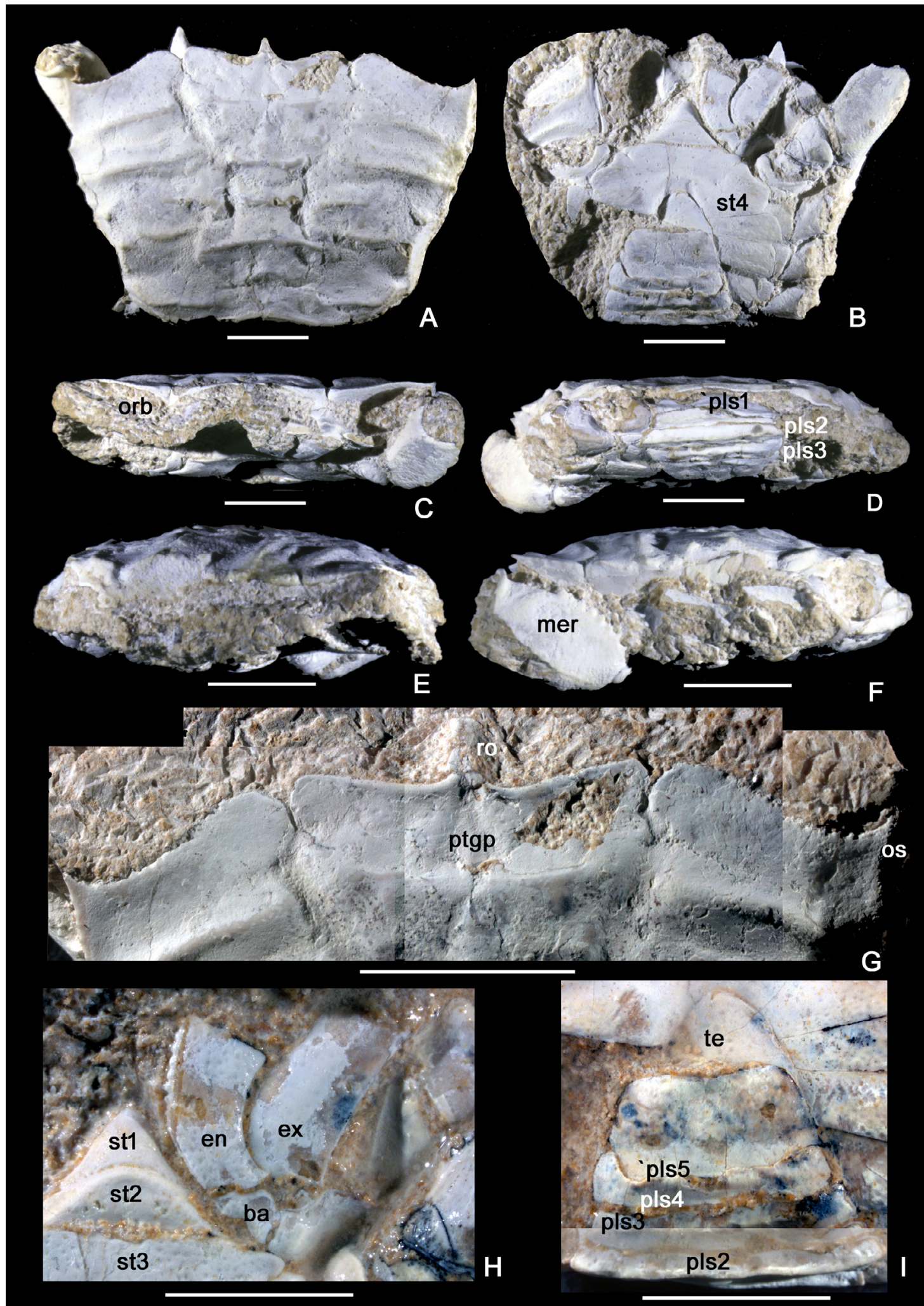

Figure 3 A-H, Icriobranchiocarcinus rodas Vega, n. sp., holotype IGM 11515 from the lower Maastrichtian Arroyo Grande Formation, Cuba. Scale bars $=1 \mathrm{~cm}$. 


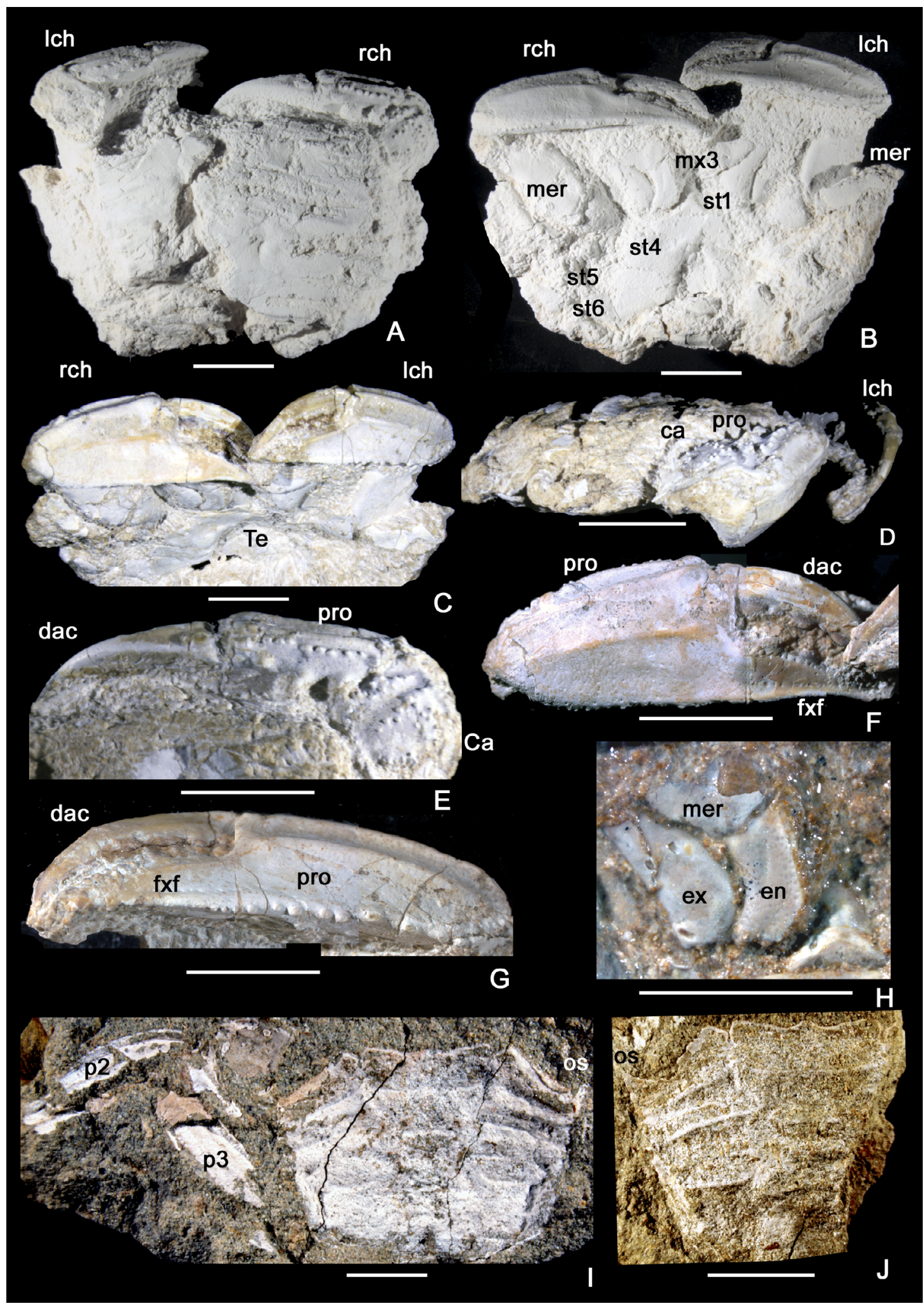

Figure 4 A-H, Icriobranchiocarcinus rodas Vega, n. sp., from the lower Maastrichtian Arroyo Grande Formation, Cuba. A-H, paratype IGM 11516: dorsal (A), ventral (B), frontal (C), right lateral (D), dorsal right cheliped (E), outer right chela (F), ventral margin of left chela (G), right third maxilliped close up views (H). I, J, Icriobranchiocarcinus tzutzu Vega, 2018 in Vega et al., 2018, from the lower Maastrichtian Ocozocoautla Formation, Chiapas, Mexico. Paratype IHNFG-5333, dorsal view of carapace (I), holotype IHNFG-5502, dorsal view of incomplete carapace (J). Scale bars $=1 \mathrm{~cm}$. 


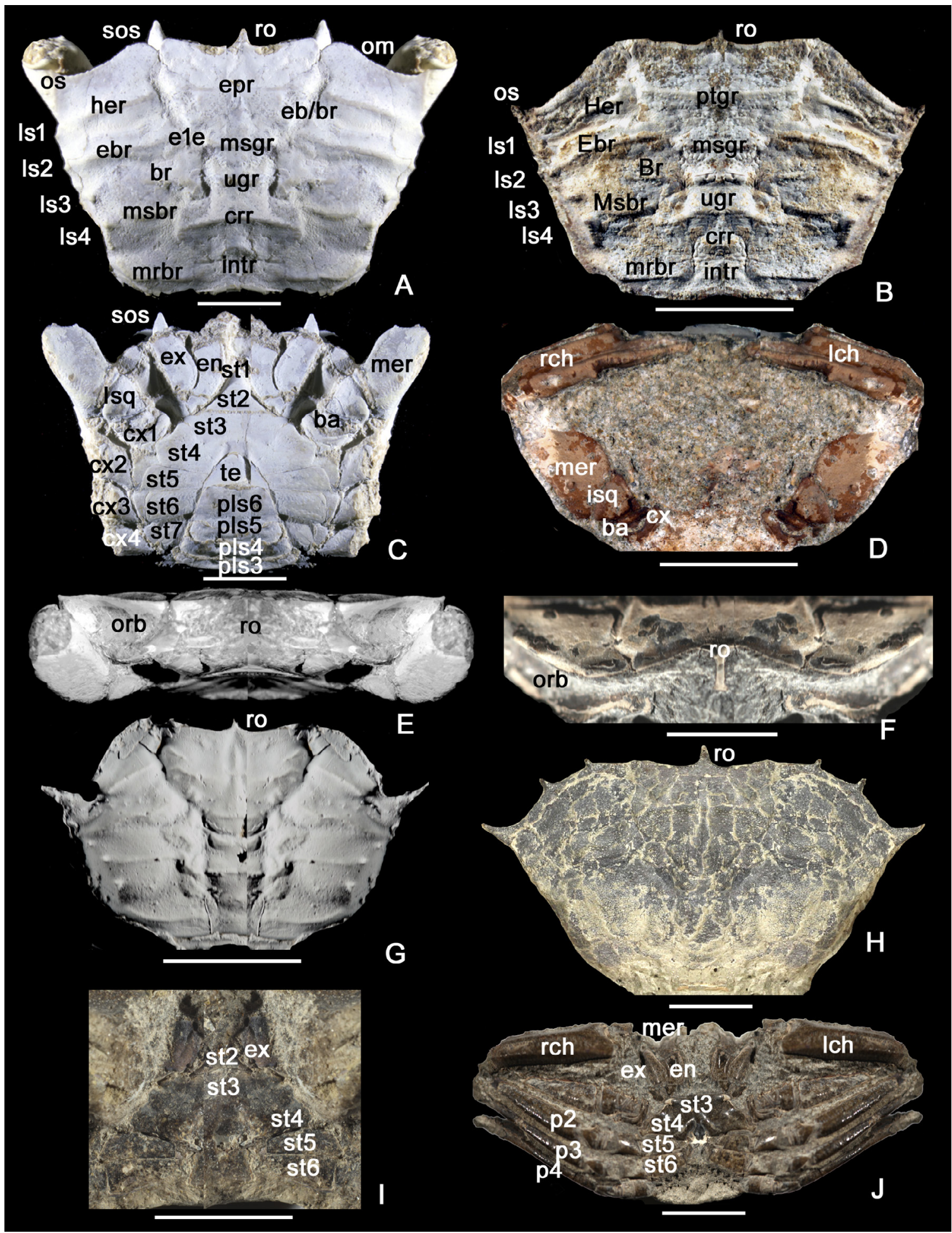

Figure 5 A, C, E, Icriobranchiocarcinus rodas Vega, n. sp., from the lower Maastrichtian Arroyo Grande Formation, Cuba. Holotype IGM 11515: dorsal (A), ventral (B), frontal (C) views of carapace. B, D, Icriobranchiocarcinus tzutzu Vega, 2018 in Vega et al., 2018, from the lower Maastrichtian Ocozocoautla Formation, Chiapas, Mexico. Paratype IHNFG-5333, reconstruction of dorsal carapace based on inverted mirror image (B), reconstruction of ventral carapace based on inverted mirror image, same specimen (D). F, H, J, Icriocarcinus xestos Bishop, 1988, from the lower Maastrichtian El Rosario Formation, Punta Santo Tomás, Baja California, Mexico, specimen IGM 6625-1, close up of frontal view (F), specimen IGM 7722 ventral view of carapace (J); lower Maastrichtian Point Loma Formation, Carlsbad Research Center, California, paratype SDSNH 26113, dorsal view of carapace (H). G, I, Branchiocarcinus flectus (Rathbun, 1923) from the upper Maastrichtian Owl Creek Formation, Tippah County, Mississippi, specimen MMNS IP-4388 dorsal view of carapace (G); Scale bars = $1 \mathrm{~cm}$. 
2 to 6 visible in ventral position, somite 2 folded, somite 1 visible only in dorsal position; chelipeds subequal, robust, with meral spines on ventral surface, carpus robust, spiny; propodus robust, with strong transverse outer middle transverse ridge, ventral margin with longitudinal line of fine granules, dorsal surface with three longitudinal ridges, outermost smooth, middle with small tubercles and innermost with strong tubercles; third maxillipeds strong, elongated, subrectangular exopodite, endite slightly curved, with weak middle longitudinal groove, merus semiquadrate, half the length of endite.

Description.- Carapace large when compared with Branchiocarcinus but about the average size of Icriocarcinus, inverted subtrapezoidal, one-third wider than long, widest at level of sharp, slightly outside directed, sharp triangular orbital spines; central portion of anterior margin slightly curved, fissures mark division with finely serrated supraorbital margin, curved toward orbital spine, rostrum short compared to that of Icriocarcinus, lateral margin straight, with four sharp, short spines, separated from each other by similar distances, slightly inclined backwards to short, curved posterolateral margin; posterior margin slightly convex; dorsal carapace regions marked by strong transverse ridges and relatively deep grooves; orbits wide, subovate, with prominent, sharp suborbital spine at level of exopodite of third maxillipeds, strong suborbital spine projected beyond the anterior margin, so it can be seen in dorsal position; dorsal carapace regions marked by strong transverse ridges and relatively deep grooves; sharp transverse ridges on protogastric, mesogastric, urogastric, cardiac, intestinal, hepatic, epibranchial, branchial, mesobranchial and metabranchial regions; cardiac with sharp anterior tip; sternum clearly divided from sternite 1 to sternite7, with strong inverted triangular lateral process from sternite 4 to sternite 6; (female?) pleon wide, triangular, widest at level of pleonal somite 6 ; telson triangular, pleonal somite 6 one-third wider and about twice the length of telson; pleonal somite 5 slightly shorter but one-third wider than pleonal somite 6 , pleonal somite 4 half the length but onethird wider than pleonal somite 5, pleonal somite 3 folded in the middle by transverse ridge, twothirds wider but about half the length of pleonal somite 4 , pleonal somite 2 folded in the middle by transverse ridge, about as long but one-third narrower than pleonal somite 3 , pleonal somite 1 only visible in dorsal position, semi-triangular, as wide as pleonal somite 2 but twice its length; chelipeds subequal, robust, with at least two meral spines on ventral surface, carpus robust, spiny in dorsal view; propodus robust, subrectangular elongated, with strong transverse outer middle transversal smooth ridge, ventral margin marked by ridge with longitudinal fine granules, dorsal surface of propodus with three longitudinal ridges, outermost smooth, middle with at least 8 small tubercles and innermost with four strong tubercles; other pereiopods not completely preserved but long and slender; third maxillipeds strong, elongated, subrectangular exopodite, endite slightly curved toward center of mouth, with weak middle longitudinal groove, merus semiquadrate, half the length of endite.

Discussion.- Icriobranchiocarcinus tzutzu Vega, 2018, differs from the new species in having slightly curved anterior margin without a row of small tubercles on supraorbital margin, lacking the strong, anteriorly projected suborbital spine, having a relatively smaller chelae with strongly-marked outer, longitudinal ridges, and having a less sharp spiny dorsal surface of carpus. In addition, dorsal regions are marked by less sharp transverse ridges and weaker grooves. Icriobranchiocarcinus tzutzu appears to be adapted to a relatively coarse grained sediment, very similar to sandstones containing Icriocarcinus xestos Bishop, 1988, from the lower Maastrichtian Point Loma Formation, California and El Rosario Formation, Baja California, Mexico. Icriobranchiocarcinus rodas Vega n. sp. is associated to reef carbonates of a similar age of the Arroyo Grande Formation, Cuba, which also includes undescribed raninoids and other still unidentified decapods. Therefore, it appears the paleobiodiversity was higher in the calcareous sediments of Cuba. 


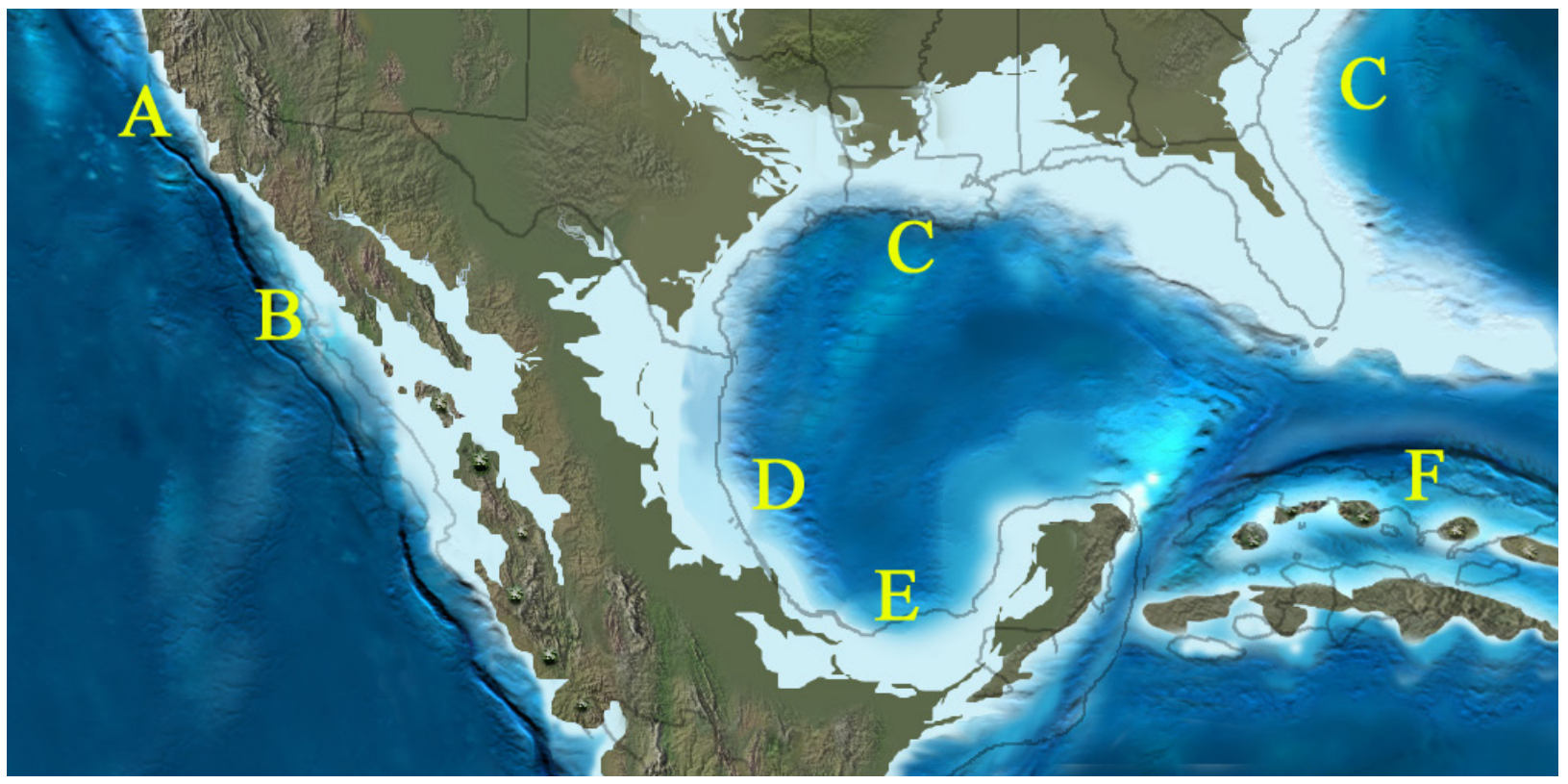

Figure 6 Paleobiogeographic distribution of icriocarcinid crabs during Late Cretaceous (70-66 Ma) in the Caribbean and southern North America. A = Branchiocarcinus pacificus; B = Icriocarcinus xestos; C = B. flectus; D = B. cornatus; E = Icriobranciocarcinus tzutzu; $\mathrm{F}=$ Icriobranchiocarcinus rodas Vega, $\mathrm{n}$. sp. Image courtesy of Ron Blakey.

\section{Conclusions}

The wide distribution of the Icriocarcininae during the latest Cretaceous is confirmed by the occurrence of Icriobranchiocarcinus rodas. Other records for this extinct subfamily at the $\mathrm{K} /$ Pg event includes: Branchiocarcinus cornatus Feldmann and Vega in Vega et al. (1995) in the lower Maastrichtian Cárdenas Formation of San Luis Potosí, Mexico; B. flectus (Rathbun, 1923) in the Maastrichtian of Mississippi and New Jersey, USA (Phillips et al., 2013; Landman et al., 2007); B. pacificus Nyborg, Ossó and Vega, 2014, from the latest Maastrichtian of California (USA) (Nyborg et al., 2014); Icriocarcinus xestos Bishop, 1988, in the lower Maastrichtian El Rosario (Baja California, Mexico), the lower Maastrichtian of Baja California (Mexico) and the Point Loma Formation, California; and Icriobranchiocarcinus tzutzu from the lower Maastrichtian of Chiapas (Vega et al., 2018). This suggests that the Icriocarcininae (possibly derived from the Lithophilacinae during the Cenomanian of Europe), had a major radiation at the end of the Cretaceous Period, reaching an extensive distribution and a wide diversity of shapes, sizes, and morphological details that suggest a high ende- mism of the genera and species of this family, especially during Maastrichtian times in North America (Figure 6) and possibly in Europe, too. The Cuban species were found in association to Graptocarcinus collinsi Vega, 2018, and other unidentified decapods, therefore the paleobioversity was higher in the calcareous sediments of Cuba.

\section{Acknowledgements}

Our sincere gratitude to reviewers Dr. Rodney M. Feldmann (Kent State University, Ohio) and Alessandro Garassino (Loma Linda University, California) for their kind suggestions to improve the original manuscript, also to Reinaldo Rojas-Consuegra helped with regional geology information. We wish to thank Dr. Antoni Camprubí and Salvador Vazquez for their fast and kind editorial treatment of this contribution. Finally, our sincere gratitude to Dr. Jesús Alvarado-Ortega and MSc Violeta Romero-Mayén, from the Colección Nacional de Paleontología, Instituto de Geología, UNAM, for curatorial support. 


\section{References}

Arano-Ruiz, A., Vinola-López, L.W., RojasConsuegra, R., Borges-Sellen, C.R., 2018, Re-evaluation of the taxonomic status of Vegaranina (Crustacea: Raninidae) from the Late Cretaceous of Cuba, with description of a new species: Zootaxa 4527(4), 588-594. https://doi.org/10.11646/ zootaxa.4527.4.10

Bishop, G.A., 1988, Two crabs, Xandaros sternbergi (Rathbun, 1926) n. gen., and Icriocarcinus xestos n. gen., n. sp., from the Late Cretaceous of San Diego County, California, U.S.A., and Baja California Norte, Mexico: Transactions of the San Diego Society of Natural History 21, 245-257. https://doi.org/10.5962/bhl.part.24586

Ehrenberg, K., 1944, Ergaenzende Bemerkungen zu den Sein erzeit aus dem Miozaen von Burgschleinitz Beschriebenen Gangkernen und Buuten dekapoder Krebse: Paläontologische Zeitschrift 23(3-4), 354359. https://doi.org/10.1007/BF03160443

Feldmann, R. M., Vega, F., Tucker, A. B., García-Barrera, P., Avendaño, J., 1996, The oldest record of Lophoranina (Decapoda: Raninidae) from the late Cretaceous of Chiapas, southeastern Mexico: Journal of Paleontology 70 (2), 296-303. https://doi. org/10.1017/S0022336000023386

Guinot, D., 1977, Propositions pour une nouvelle classification des Crustacés Décapodes Brachyoures: Comptes Rendus Hebdomadaires des Séances de l'Académie des Sciences, 285 (D), 1049-1052.

Iturralde-Vinent, M.A., 2006, Meso-Cenozoic Caribbean paleogeography: implications for the historical biogeography of the region: International Geology Review 48(9), 791-827. https://doi. org/10.2747/0020-6814.48.9.791

Landman, N.H., Johnson, R.O., Garb, M.P., Edwards, L.E., Kyte, F.T., 2007. Cephalopods from the Cretaceous/Tertiary boundary interval on the Atlantic Coastal Plain, with a description of the highest ammonite zones in North America, part 3, Manasquan River Basin, Monmouth County, New Jersey: American Museum of Natural History Bulletin 303, 1-122.

Laurent, Saint, de, M., 1980, Sur la classification et la phylogénie des Crustacés Décapodes Brachyoures. I. Podotremata Guinot, 1977, et Eubrachyura sect. nov: Comptes Rendus Hebdomadaires des Séances de l'Académie des Sciences, 290 (D), 1265-1268.

Linares-Cala, E., 2014, Arroyo Grande, Formación; in Léxico Estratigráfico de Cuba, Instituto de Geología y Paleontología, Habana, Cuba, 83-84 p.

Nyborg, T., Ossó, À., Vega, F.J., 2014, A new species of icriocarcinid crab (Crustacea, Portunoidea) from the uppermost Cretaceous of California, USA: palaeobiogeographic implications: Scripta Geologica 147, 83-93.

Phillips, G.E., Nyborg, T., Vega, FJ., 2013, Icriocarcinidae: a family of portunoid crabsfrom the Upper Cretaceous of North America: Paläontological Zeitschrift 88(2), 139-158. https://doi.org/10.1007/ s12542-013-0190-4

Pszczólkowski, A., 2002, Crustacean burrows from upper Maastrichtian deposits of South-Central Cuba: Bulletin of the Polish Academy of Earth Sciences 50(2), 147-163.

Rafinesque, C.S., 1815, Analyse de la Nature, ou Tableau de l'Univers et des corps organisés: L'Imprimerie de Jean Barravecchia, Palermo, Italy, $224 \mathrm{p}$.

Rathbun, M.J., 1923, Decapod crustaceans from the Upper Cretaceous of North Carolina. In: Stephenson, L.W. (Ed.), The Cretaceous formations of North Carolina: Raleigh: North Carolina Geological Survey, 403-408.

Števčić, Z., 2005, The reclassification of brachyuran crabs (Crustacea: Decapoda Brachyura): Natura Croatica 14 (Suppl. 1), 1-159.

Van Straelen, V., 1934, Contribution à l'étude des crustacés décapodes fossiles de la Catalogne: Géologique des Pays Catalans 3(25), 1-6. 
Van Straelen, V., 1936, Crustacés décapodes nouveaux ou peu connus de l'époque Crétacique: Bulletin du Musée Royale d'Histoire Naturelle de Belgique 12(45), 1-49. Varela, C., Rojas-Consuegra, R., 2009, Crustáceos (Decapoda: Brachyura) fósiles de Cuba: Solenodon 8, 118-123.

Varela, G., Rojas-Consuegra, R., 2011, El registro fósil de los crustáceos decápodos (Arthropoda, Crustacea) marinos de Cuba, In: IX Congreso Cubano de Geología, Memorias, 1-10.

Vega, F.J., Feldmann, R.M., Sour-Tovar, F., 1995, Fossil crabs (Crustacea: Decapoda) from the Late Cretaceous Cárdenas Formation, EastCentral Mexico: Journal of Paleontology 69(2), 340-350.https://doi.org/10.1017/ S0022336000034661
Vega, F.J., Charbonnier, S., Gómez-Pérez, L.E., Coutiño, M.A., Carbot-Chanona, G., Távora, V. A., Serrano-Sánchez, M.L., Téodorif, D., Hernández-Monzón, O. 2018, Review and additions to the Maastrichtian (Late Cretaceous) crustacea from Chiapas, Mexico: Journal of South American Earth Sciences 85, 325-344. https://doi. org/10.1016/j.jsames.2018.05.017

Vega, F.J., Borges-Sellén, C.R., Aguilar-Pérez, J., Arano-Ruiz, A.F., Viñola-López, L.W., Barragán, R., 2020, On a new species of Graptocarcinus Roemer, 1887 (Brachyura, Dynomenidae, Graptocarcininae) from the Late Cretaceous of SW Cuba: Neues Jahrbuch für Geologie und Palaeontologie, Abhandlungen 296(1-2), 211-216. https:// doi.org/10.1127/njgpa/2020/0884 